\title{
Reproduction of the Atlantic Forest endemic star-throated antwren, Rhopias gularis (Aves: Thamnophilidae)
}

\author{
D. F. Perrella ${ }^{a}$, C. H. Biagolini Junior ${ }^{b}$, L. Ribeiro-Silva ${ }^{a}$, P. V. Q. Zima ${ }^{a}$ and M. R. Francisco ${ }^{\text {* }}$ \\ aPrograma de Pós-graduação em Ecologia e Recursos Naturais - PPGERN, Universidade Federal de São Carlos - UFSCar, \\ Rodovia Washington Luís, Km 235, CEP 13565-905, São Carlos, SP, Brazil \\ bPrograma de Pós-graduação em Diversidade Biológica e Conservação - PPGDBC, Universidade Federal de São Carlos - \\ UFSCar, Campus Sorocaba, Rodovia João Leme dos Santos, Km 110, CEP 18052-780, Sorocaba, SP, Brazil \\ 'Departamento de Ciências Ambientais, Universidade Federal de São Carlos - UFSCar, Campus Sorocaba, Rodovia João \\ Leme dos Santos, Km 110, CEP 18052-780, Sorocaba, SP, Brazil \\ *e-mail: mercival@ufscar.br
}

Received: September 17, 2015 - Accepted: March 7, 2016 - Distributed: May 31, 2017

\begin{abstract}
The Thamnophilidae are one of the most speciose Neotropical bird families, yet aspects of their natural history remain poorly documented. Here we provide information on breeding phenology, the length of incubation and nestling periods, parental care, and nesting success of the Star-throated Antwren, Rhopias gularis, an Atlantic Forest endemic. The data are discussed in light of life history theories. We found 27 active nests during two breeding seasons (2013/2014 and 2014/2015) at Carlos Botelho State Park in southeastern Brazil. Nesting activities were observed from September to January. Incubation and nestling periods lasted $16.8 \pm 0.6$ and $11.0 \pm 0.86$ days, respectively, as with most other antbirds. Males and females shared equally in incubation and nestling provisioning. The small clutch size of two eggs is that most commonly found in tropical birds and is hypothesized to have evolved due to increased nest predation rates. However, our data was not consistent with this hypothesis as the nest survival probability was high (57\%). This is one of only a handful of studies that provide comprehensive information on the breeding biology of a Thamnophilid species in undisturbed habitat.
\end{abstract}

Keywords: breeding phenology, life history, nesting behavior, nesting success, parental care.

\section{Reprodução da choquinha-de-garganta-pintada, Rhopias gularis (Aves: Thamnophilidae), uma espécie endêmica da Mata Atlântica}

\section{Resumo}

A Família Thamnophilidae compreende as diversas espécies de chocas e papa-formigas e compõem um dos maiores grupos de aves neotropicais. Apesar do elevado número de espécies, aspectos da história natural permanecem pouco documentados. No presente estudo são fornecidas informações sobre fenologia reprodutiva, duração dos períodos de incubação e permanência dos filhotes no ninho, cuidado parental e sucesso reprodutivo da choquinha-de-garganta-pintada, Rhopias gularis, endêmica da Mata Atlântica, enfocando teorias de história de vida. Foram encontrados 27 ninhos ativos durante duas temporadas reprodutivas (2013/2014 e 2014/2015) no Parque Estadual Carlos Botelho, no sudeste do Brasil. Atividades de nidificação foram observadas de setembro a janeiro. Períodos de incubação e permanência dos filhotes nos ninhos duraram $16.8 \pm 0.6$ e $11.0 \pm 0.86$ dias, respectivamente, sendo similares aos de outras chocas e papa-formigas. Machos e fêmeas dividiram as funções de incubação e alimentação dos ninhegos em taxas similares. As ninhadas de dois ovos seguem o padrão mais comum para Passseriformes tropicais, mas os dados apresentados não se mostraram consistentes com a hipótese de que a evolução de ninhadas menores está relacionada às altas taxa de predação de ninhos nesta região, uma vez que foi observada alta probabilidade de sobrevivência (57\%). O presente estudo é um dos poucos a proporcionar informações abrangentes sobre a biologia reprodutiva de um Thamnophilidae em uma área preservada.

Palavras-chave: fenologia reprodutiva, história de vida, comportamento de nidificação, sucesso reprodutivo, cuidado parental. 


\section{Introduction}

The Thamnophilidae Swainson, 1824 are a family of over two hundred species endemic to the Neotropical region and includes the typical antbirds. Their diversity is greatest in the Amazon basin, where they are mainly found in the forest understory and subcanopy (Ridgely and Tudor, 1994). Within this family, the Myrmotherula Sclater, 1858 antwrens form a complex of 32 species of small, short-tailed forest birds (Ridgely and Tudor, 1994) whose natural history, including reproductive biology, has been little studied.

Descriptions of nests and eggs are available for 10 of the 32 species (reviewed in Perrella et al., 2015), but other life-history data are, for the most part, absent. Incubation and nestling periods are reported only for the White-flanked and Slaty Antwrens, M. axillaris (Vieillot, 1817) and M. schisticolor (Lawrence, 1865), respectively, (Skutch, 1945, 1946, 1969). Parental care is described for these species as well as the Fulvous-bellied Antwren, Epinecrophylla fulviventris (Lawrence, 1862) (Skutch, 1946, 1969). However, these were based on only a few nests and the breeding phenology was not determined.

The Star-throated Antwren, Rhopias gularis (Spix, 1825) is endemic to the Atlantic Forest of southeastern Brazil where it is found in the forest understory from southern Bahia to northern Rio Grande do Sul (Ridgely and Tudor, 1994). It is small $(9.5 \mathrm{~cm})$ and slightly sexually dimorphic with the forehead varying between gray in the males and buffy in females. Females also have larger white spots on the black throat (Ridgely and Tudor, 1994; Zimmer and Isler, 2003). Here we report detailed information on breeding phenology, the length of incubation and nestling periods, nesting success, and nest attendance of the Star-throated Antwren, in a preserved Atlantic Forest continuum in São Paulo state, Brazil.

\section{Material and Methods}

\subsection{Study area}

Star-throated Antwren nests were studied at Carlos Botelho State Park (PECB) (240 06' 55"- 24 14' 41" S and $\left.47^{\circ} 47^{\prime} 18^{\prime \prime}-48^{\circ} 07^{\prime} 17^{\prime \prime} \mathrm{W}\right)$; a 37,644 ha patch of well-preserved Atlantic Forest in the state of São Paulo. The park is part of the Serra de Paranapiacaba, one of the largest, most intact, remnants of Atlantic Forest in southeast Brazil. The elevation ranges from 20 to $1,000 \mathrm{~m}$ above sea level and mean annual temperature between 18 and $20^{\circ} \mathrm{C}$, with annual precipitation from 1,500 to 2,200 mm (Ferraz and Varjabedian, 1999). Field work took place at an altitude between $714-837 \mathrm{~m}$ in submontane rain forest (Oliveira-Filho and Fontes, 2000).

\subsection{Field procedures}

Fieldwork was conducted during two breeding seasons, one from September 2013 to February 2014, and the other from September 2014 to February 2015. Nests were searched for five days of the week, about 5 hours per day, following $\sim 7 \mathrm{~km}$ of trails and $\sim 3 \mathrm{~km}$ of streams in the primary forest interior, especially when adults were heard vocalizing. Once found, nests were monitored every 1-3 days. During the laying period they were checked between 09:00h-10:00h to insure that eggs laid that morning would be counted.

We considered the incubation period as being from the first day of incubation (female was incubating or the eggs were warm) to the day before hatching and the nestling period from the day the chicks hatched to the day before fledging (Winkler, 2004; Oliveira et al., 2010; Freitas and Francisco, 2012). Each egg / chick was considered separately and for nests in which hatching or fledging were asynchronous we assumed that laying order predicted hatching and fledging order. Nestlings were never touched to avoid interfering with nestling periods (Skutch, 1945). When eggs or nestlings disappeared prior to hatching or fledging, we assumed it a result of nest predation, and when nests were no longer cared for (three days without seeing the parents), abandonment. Nest attendance during laying, incubation, and nestling stages were observed with $8 \times 42 \mathrm{~mm}$ binoculars or video, over one hour sessions between 06:00h-10:00h.

\subsection{Statistical analyses}

The participation of both sexes in incubation, nestling provisioning, fecal sac removal, and brooding were measured as rates of the number or duration of events per hour observed. Differences in the investments made between the sexes for each activity were determined using the Wilcoxon-Mann-Whitney test in R software 2.15.3 (R Development Core Team, 2013). Descriptive statistics were presented as mean \pm standard deviation (SD). Nests that were found prior to incubation were used to estimate the incubation period per egg. Nest survival probability for the whole nesting cycle was estimated using the method proposed by Mayfield (1961). Average incubation and nestling periods were used as exponents, and the laying period was not considered.

\section{Results}

We analyzed 27 active nests: 12 in 2013/2014 and 15 in 2014/2015. In 2013, the first nest was found on 24 October, with an adult incubating two eggs, and the last nest abandoned on 10 January 2014. In 2014 the first nest was found on 2 September with $1 \mathrm{egg}$, and the last nestling fledged on 8 January 2015.

Clutch size was invariably two $(n=27$ nests). Four nests were found with one egg and one was found with two prior to incubation. In those which had one egg, the second was laid one (two nests) or two (two nests) days later. Incubation began the morning the female laid the second egg. In the nest found with two cold eggs, incubation commenced the following day. Incubation periods were 16 (3 eggs), 17 (6 eggs), or 18 days ( 1 egg), averaging 16.8 days \pm 0.6 ( 10 eggs from five nests).

Over a total of 20 hours of observation across seven different nests, females and males were found to share the incubation with a total of 578 minutes for females and 512 minutes for males. There was no difference in 
the average time spent incubating per hour between sexes $(28.9 \pm 24.8$ minutes for females, $25.6 \pm 24.8$ for males, $\mathrm{W}=218, \mathrm{p}=0.63)$. Eggs were incubated on average $91 \%$ of the time.

Hatching was synchronous in four nests and asynchronous in three nests, with an approximately 24 hour interval. Nestling periods of 12 young from six nests were $10(n=3)$, $11(\mathrm{n}=6), 12(\mathrm{n}=2)$ or 13 days $(\mathrm{n}=1)(11.0 \pm 0.86)$. In 22 hours of observations at nine nests, nestlings were provisioned for 2-14 times/hour, with more or less equal participation between parents (females $3.3 \pm 2$ times $/ \mathrm{hr}$, males $3.3 \pm 2.2$ times $/ \mathrm{hr}, \mathrm{W}=243, \mathrm{p}=0.99)$. Fecal sacs were removed 0-4 times per hour $(1.23 \pm 1.1)$, in similar proportions by females $(n=16)$, and males $(n=11, W=277.5$, $\mathrm{p}=0.36$ ). Of these, $89 \%$ were carried away from the nest and $11 \%$ consumed. During these observations, males and females were each recorded brooding the nestlings 16 times. The duration of brooding sessions were similar between sexes (female $13.8 \mathrm{~min} \pm 14.1$, male $18.3 \mathrm{~min} \pm 16.3$, $\mathrm{W}=203, \mathrm{p}=0.36$ ).

Three nests were abandoned during incubation (11\%), seven were lost to predation (26\%) and 17 were successful (63\%). Nests were abandoned in late December $2013(\mathrm{n}=1)$ and early January $2014(\mathrm{n}=2)$. Only one egg in a total of 40 (that were cared for) did not hatch $(2.5 \%)$. Mayfield overall nest survival probability was $57 \%$.

\section{Discussion}

\subsection{Breeding phenology and nesting cycle}

There is very little information available regarding the breeding season and nesting cycle lengths in the Thamnophilidae. In equatorial regions, the Spotted Antbird Hylophylax naevioides (Lafresnaye, 1847) reproduced during five to six months of the year (Styrsky and Brawn, 2011) and the White-plumed Antbird Pithys albifrons (Linnaeus, 1766), from the Amazon basin, during 10 months (Oniki and Willis, 1982). These are at least two months longer than for the Star-throated Antwren. Although this comparison is not ideal as the species are from different genera, the data seem to follow the pattern of shorter breeding seasons at higher latitudes. This has been well-documented in the northern hemisphere (Johnston, 1954; Cooper et al., 2005), but only recently in the neotropics (see Davanço et al., 2013). In temperate regions, shorter breeding seasons often have constrained nesting cycles, i.e. incubation plus nestling periods (for review Cooper et al., 2005). However, this does not seem to occur in the Mymotherula complex. The Slaty and the White-flanked Antwrens in Central America had a nesting cycle of 23 or 24 days (Skutch, 1945, 1969) but it is 28 days in the Star-throated Antwren.

\subsection{Clutch sizes and nesting success}

Within the Myrmotherula complex clutch size invariably consists of two eggs (Stone, 1918; Snethlage, 1935; Skutch, 1946, 1969; Wetmore, 1972; Oniki and Willis, 1982; Solano-Ugalde et al., 2007). This is the most common clutch size among other tropical forest passerines
(Skutch, 1945, 1985; Jetz et al., 2008). Skutch's (1949) hypothesis was that, in the tropics, higher nest predation rates would favor smaller clutch sizes. This is apparently not applicable to the Star-throated Antwren, which has a relatively high nest success rate, compared to other tropical birds, which are generally around 10-20\% (Willis, 1974; Robinson et al., 2000; Roper, 2005; Ryder et al., 2008).

\subsection{Nest attendance}

It has long been hypothesized that insectivorous birds spend more time foraging than frugivorous species because fruits are easier to find than arthropods. As a consequence, offspring production in insectivorous species is highly dependent on provisioning by both the female and male, whilst a frugivorous diet permits male desertion in many bird groups (Snow, 1985; Cockburn, 2006). In the proposal of his theory, David Snow spoke of antbirds as an example of exclusively insectivorous birds, although empirical data on antbird parental care was surprisingly scarce. Male antbirds have been reported to share incubation, nestling provisioning and brooding with females, and are sometimes even more attentive than females (Skutch, 1969; Greenberg and Gradwohl, 1983; Zimmer and Isler, 2003). Our results suggest that sexes are equally attentive, supporting this hypothesis.

Another poorly investigated aspect of nesting attendance in Neotropical birds involves the removal of fecal sacs. Passerine nestlings often produce fecal sacs that can be easily removed or consumed by adults as keeping the nest clean may help avoid nest predation (Petit et al., 1989; Winkler, 2004). It has been hypothesized that the proportion of fecal sacks eaten versus those carried away is associated with energetic costs in northern hemisphere birds. More specifically Tree Swallows, Tachycineta bicolor (Vieillot, 1808), American Robins, Turdus migratorius Linnaeus, 1766, and Red-winged Blackbirds, Agelaius phoeniceus (Linnaeus, 1766), (Hard et al., 1991). Adults tend to swallow the fecal sacs when they stay at the nest, e.g. brooding after feeding. On the other hand, when the nestlings are older and brooding becomes less necessary, the parents tend to carry the fecal sacs away from the nest (Hard et al., 1991). Typical antbirds have been shown to remove fecal sacs (Sick, 1997; Sheldon and Greeney, 2008). In Star-throated Antwrens fecal sacs were most often removed by the individual leaving at each switch in incubation and brooding by the parents. The few occasions when a parent bird consumed the fecal sac (11\%) were all prior to brooding.

In conclusion, this is one of few studies to provide comprehensive information on the breeding biology of a species of Thamnophilidae, based on a reasonable sample size and in undisturbed habitat. Comparisons with other species give support to the pattern of longer breeding seasons nearer the equator, despite the lack of variation in clutch sizes and duration of nesting cycles. Our data was also consistent with the previous findings that males and females provide similar proportions of parental care within the Thamnophilidae. 


\section{Acknowledgements}

This paper is due to SISBIOTA network - Top predators. The authors thank the Brazilian agencies Fundação de Amparo à Pesquisa do Estado de São Paulo (FAPESP, 2010/52315-7), and Conselho Nacional de Desenvolvimento Científico e Tecnológico (CNPq, 563299/2010-0) for financial support, Instituto Florestal do Estado de São Paulo (IF), and ICMBio for permits for field work at Carlos Botelho State Park. We especially thank MA Pizo Ferreira and an anonymous referee for important comments on early versions of this manuscript and Jeremy K. Dickens for English text revision.

\section{References}

COCKBURN, A., 2006. Prevalence of different models of parental care in birds. Proceedings Biological Sciences, vol. 273, no. 1592, pp. 1375-1383. http://dx.doi.org/10.1098/rspb.2005.3458. PMid:16777726.

COOPER, C.B., HOCHACHKA, W.M. and DHONDT, A.A., 2005. Latitudinal trends in within-year reoccupation of nest boxes and their implications. Journal of Avian Biology, vol. 36, no. 1, pp. 31-39. http://dx.doi.org/10.1111/j.0908-8857.2005.03319.x.

DAVANÇO, P.V., OLIVEIRA, L.S., SOUSA, L.M.S. and FRANCISCO, M.R., 2013. Breeding life-history traits of the Pale-breasted Thrush (Turdus leucomelas) in southeastern Brazil. Ornitologia Neotropical, vol. 24, pp. 401-411.

FERRAZ, L.P.M. and VARJABEDIAN, R., 1999. Evolução histórica da implantação e sintese das informações disponiveis sobre o Parque Estadual Carlos Botelho. São Paulo: Secretaria do Meio Ambiente. 95 p.

FREITAS, M.S. and FRANCISCO, M.R., 2012. Reproductive life history traits of the Yellowish Pipit (Anthus lutescens). The Wilson Journal of Ornithology, vol. 124, no. 1, pp. 119-126. http://dx.doi.org/10.1676/11-038.1.

GREENBERG, R. and GRADWOHL, J., 1983. Sexual roles in the dot-winged antwren (Microrhopias quixensis), a Tropical Forest Passerine. The Auk, vol. 100, pp. 920-925.

HARD, P.L., WEATHERHEAD, P.J. and MCRAE, S.B., 1991. Parental consumption of nestling feces: good food or sound economics? Behavioral Ecology, vol. 2, no. 1, pp. 69-76. http:// dx.doi.org/10.1093/beheco/2.1.69.

JETZ, W., SEKERCIOGLU, C.H. and BÖHNING-GAESE, K., 2008. The worldwide variation in avian clutch size across species and space. PLoS Biology, vol. 6, no. 12, pp. 2650-2657. http://dx.doi.org/10.1371/journal.pbio.0060303. PMid:19071959.

JOHNSTON, R.F., 1954. Variation in breeding season and clutch size in Song Sparrows of the Pacific Coast. The Condor, vol. 56, no. 5, pp. 268-273. http://dx.doi.org/10.2307/1364850.

MAYFIELD, H., 1961. Nesting success calculated from exposure. The Wilson Bulletin, vol. 73, no. 3, pp. 255-261.

OLIVEIRA, L.S., SOUSA, L.M.S., DAVANÇO, P.V. and FRANCISCO, M.R., 2010. Breeding behaviour of the Lined Seedeater (Sporophila lineola) in southeastern Brazil. Ornitologia Neotropical, vol. 21, pp. 251-261.
OLIVEIRA-FILHO, A.T. and FONTES, M.A.L., 2000. Patterns of floristic differentiation among Atlantic Forests in Southeastern Brazil and the influence of climate. Biotropica, vol. 32, no. 4b, pp. 793-810. http://dx.doi.org/10.1111/j.1744-7429.2000.tb00619.x.

ONIKI, Y. and WILLIS, E.O., 1982. Breeding records of birds from Manaus, Brazil: Formicariidae to Pipridae. Brazilian Journal of Biology $=$ Revista Brasileira de Biologia, vol. 42, no. 3, pp. 563-569.

PERRELLA, D.F., BIAGOLINI-JÚNIOR, C.H., RIBEIRO-SILVA, L., ZIMA, P.V.Q., GALETTI JUNIOR, P.M. and FRANCISCO, M.R., 2015. Nest, eggs, and nestlings of the Atlantic Forest endemic Star-throated Antwren (Rhopias gularis). The Wilson Journal of Ornithology, vol. 127, no. 2, pp. 322-326. http://dx.doi. org/10.1676/wils-127-02-319-323.1.

PETIT, K.E., PETIT, L. and PETIT, D.R., 1989. Fecal sac removal: do the pattern and distance of dispersal affect the chance of nest predation? The Condor, vol. 91, no. 2, pp. 479-482. http://dx.doi. org/10.2307/1368331.

R DEVELOPMENT CORE TEAM, 2013 [viewed 10 August 2013]. $R$ : a language and environment for statistical computing [online]. R Foundation for Statistical Computing. Available from: http://www.R-project.org/

RIDGELY, R.S. and TUDOR, G., 1994. The birds of South America: the suboscine passerines. Austin: University of Texas Press. 940 p.

ROBINSON, T.R., ROBINSON, W.D. and EDWARDS, E.C., 2000. Breeding ecology and nest-site selection of Song Wrens in Central Panama. The Auk, vol. 117, no. 2, pp. 345-354. http:// dx.doi.org/10.1642/0004-8038(2000)117[0345:BEANSS]2.0.CO;2.

ROPER, J.J., 2005. Try and try again: nest predation favors persistence in a Neotropical bird. Ornitologia Neotropical, vol. 16, pp. 253-262.

RYDER, T.B., DURÃES, R., TORI, W.P., HIDALGO, J.R., LOISELLE, B.A. and BLAKE, J.G., 2008. Nest survival for two species of manakins (Pipridae) in lowland Ecuador. Journal of Avian Biology, vol. 39, no. 3, pp. 355-358. http://dx.doi. org/10.1111/j.0908-8857.2008.04290.x.

SHELDON, K.S. and GREENEY, H.F., 2008. A comparison of parental care of the Great Antshrike (Taraba major) in Costa Rica and Ecuador. Ornitologia Neotropical, vol. 19, pp. 293-297.

SICK, H., 1997. Ornitologia Brasileira. Rio de Janeiro: Editora Nova Fronteira. 912 p.

SKUTCH, A.F., 1945. Incubation and nesting periods of Central American birds. The Auk, vol. 62, no. 1, pp. 8-37.

SKUTCH, A.F., 1946. Life history of two Panamanian antbirds. The Condor, vol. 48, no. 1, pp. 16-28. http://dx.doi.org/10.2307/1364150.

SKUTCH, A.F., 1949. Do Tropical birds rear as many young as they can nourish? The Ibis, vol. 91, no. 3, pp. 430-455. http:// dx.doi.org/10.1111/j.1474-919X.1949.tb02293.x.

SKUTCH, A.F., 1969. Life Histories of Central America Birds III (families Cotingidae, Pipridae, Formicariidae, Furnariidae, Dendrocolaptidae and Picidae). Berkeley: Cooper Ornithological Society. 580 p. Pacific Coast Avifauna, no. 35.

SKUTCH, A.F., 1985. Clutch size, nesting success, and predation on nests of Neotropical birds, reviewed. Ornithological Monographs, vol. 36, no. 36, pp. 575-594. http://dx.doi.org/10.2307/40168306. 
SNETHLAGE, E., 1935. Beiträge zur Fortpflanzungsbiologie brasilianischer Vögel. Journal für Ornithologie, vol. 83, no. 4, pp. 532-562. http://dx.doi.org/10.1007/BF01905800.

SNOW, D.W., 1985. The web of adaptation: bird studies in the American Tropics. Ithaca: Cornell University Press. 176 p.

SOLANO-UGALDE, A., ARCOS-TORRES, A. and GREENEY, H.F., 2007. Additional breeding records for selected avian species in northwest Ecuador. Boletín SAO: Sociedad Antioqueña de Ornitología, vol. 17, no. 1, pp. 17-25.

STONE, W., 1918. Birds of the Panama Canal zone, with special reference to a collection made by Mr. Lindsey L. Jewel. Proceedings Academy of Natural Sciences of Philadelphia, vol. 70, no. 2, pp. 239-280.

STYRSKY, J.N. and BRAWN, J.D., 2011. Annual fecundity of a Neotropical bird during years of high and low rainfall. The
Condor, vol. 11, no. 1, pp. 194-199. http://dx.doi.org/10.1525/ cond.2011.100051.

WETMORE, A., 1972. The birds of Republic of Panamá: part 3. Washington: Smithsonian Institution Press. 605 p.

WILLIS, E.O., 1974. Populations and local extinctions of birds on Barro Colorado Island, Panama. Ecological Monographs, vol. 44, no. 2, pp. 153-169. http://dx.doi.org/10.2307/1942309.

WINKLER, D.W., 2004. Nests, eggs, and young: breeding biology of birds. In: S. PODULKA, R.W. ROHRBAUGH JUNIOR and R. BONNEY, eds. Cornell lab of Ornithology handbook of bird Biology. Princeton: Princeton University Press, pp. 8.1-8.152.

ZIMMER, K. and ISLER, M., 2003. Family Thamnophilidae (Typical Antbirds). In: J. DEL HOYO, A. ELLIOT and D.A. CHRISTIE, eds. Handbook of the birds of the world: Broadbills to Tapaculos. Barcelona: Lynx Edicions, vol. 8, pp. 448-681. 